\title{
The occurrence and effect of a protozoan parasite, Ophryocystis elektroscirrha (Neogregarinida: Ophryocystidae) on overwintering monarch butterflies, Danaus plexippus (Lepidoptera: Danaidae) from two California winter sites
}

\author{
K. L. H. LEONG, H. K. KAYA, * M. A. YOShIMURA \\ and D. F. FREY Biological Sciences Department, Cal Poly, San Luis Obispo, and \\ *Department of Nematology, University of California, Davis
}

\begin{abstract}
Monarch butterflies, Danaus plexippus, from two overwintering populations, were found to have Ophryocystis elektroscirrha spores on their scales at rates between $53 \%$ and $68 \%$. The frequency of butterflies with O.elektroscirrha spores remained about the same between sites and throughout the winter.

2. The spores, recovered from all parts of the body of the butterfly, were most numerous on the abdomen, particularly near the posterior third.

3. Butterflies with spores survived as long as those without detectable spores at $10.1^{\circ} \mathrm{C} \pm 0.4 \mathrm{SE}$ and $78.3 \%$ r.h. $\pm 0.6 \mathrm{SE}$. Insects with spores held at $19.4^{\circ} \mathrm{C}$ $\pm 0.4 \mathrm{SE}$ and $44.9 \%$ r.h. $\pm 1.5 \mathrm{SE}$ showed a significantly higher rate of moisture loss and survived a shorter period than monarch butterflies without detectable spores.
\end{abstract}

Key words. Host-parasite relationship, protozoan parasite, monarch butterfly.

\section{Introduction}

Protozoan diseases are common among insects. Many protozoan pathogens infect a number of tissues, whereas others are tissue specific (Brooks, 1988). Neogregarines contain species that are both general and specific tissue parasites (Weiser, 1963). Those that are tissue specific include Mattesia grandis McLaughlin and M.trogodermae Canning which infect the fat bodies of beetles (Brooks, 1988) and M.geminate Jouvenaz and Anthony which infects the hypodermal cells of larvae and pupae of the fire ant Solenopsis geminata (Fabricius) (Jouvenaz \& Anthony, 1979).

An unusual tissue-specific neogregarine is Ophryocystis elektroscirrha McLaughlin and Myers (Neogregarinida: Ophryocystidae) a parasite of monarch, Danaus plexippus (L.) and Florida queen butterflies, D.gilippus berenice Cramer (McLaughlin \& Myers, 1970). The asexual and sexual life cycle of this neogregarine is restricted to the larval and pupal hypodermal cells. 8-10 days after pupation, gamogony and sporogony are initiated. The restriction of the life cycle to the hypodermal cells results in the presence of spores on the scales of the adults. Under laboratory conditions, heavily infected adults cannot expand their wings and die shortly after emergence. Less severely affected adults appear normal, but McLaughlin \& Myers (1970) postulated that the infected individuals may be weaker and more susceptible to diseases and parasites.

McLaughlin \& Myers (1970) conducted a 2-year survey for the presence of O.elektroscirrha spores on the scales of adult queen butterflies and showed infection rates of $50 \%$ and $22 \%$. The prevalence of O.elektroscirrha infection among monarch butterflies and the survivability of these individuals overwintering in California is unknown. Our study involved a seasonal survey of monarch butterflies infected with the neogregarine in two California winter sites and a laboratory study to determine the longevity and body moisture losses between individuals with or without detectable spores on their bodies. 


\section{Materials and Methods}

Laboratory studies. Ninety females and ninety males were collected in December 1990 from Pismo Ranger Station (PRS) winter site $\left(35^{\circ} 70^{\prime} 31^{\prime \prime}\right.$ latitude; $120^{\circ} 37^{\prime} 52^{\prime \prime}$ longitude), San Luis County. The insects were individually weighed and identified with a number marked on the forewing discal cell. Half of the butterflies were subjected to $10.1^{\circ} \mathrm{C} \pm 0.4 \mathrm{SE}$ and $78.3 \%$ r.h. $\pm 0.6 \mathrm{SE}$ and the other half to $19.4^{\circ} \mathrm{C} \pm 0.4 \mathrm{SE}$ and $44.9 \%$ r.h. $\pm 1.5 \mathrm{SE}$. At each temperature, the butterflies were subjected to three conditions (diet) for 21 days. Petri dishes $(10 \times 100 \mathrm{~cm})$ containing a $5 \%$ honey-water mixture, deionized water, or no water were placed in specified cages. The dishes were replenished daily. Each diet was replicated three times; each replication had five females and five males. The insects were held in a $30.5 \mathrm{~cm} \times 30.5 \mathrm{~cm} \times 30.5 \mathrm{~cm}$ cage under a $9: 15 \mathrm{~h}$ light:dark cycle. The insects were observed daily. Dead insects were removed and their longevity and forewing lengths recorded before being placed individually in envelopes and stored in a freezer. At the end of 21 days the surviving butterflies were measured for their wing lengths ( $\mathrm{mm}$ ), placed individually in separate envelopes and killed by freezing. The frozen insects subsequently were freeze dried (lyophilysed) for $48 \mathrm{~h}$ and their dry weights determined to the nearest $0.001 \mathrm{~g}$ with a Mettler balance (Sartorius, no. 1518). The abdomen of these butterflies were removed and processed for neogregarine spores. The experiment was repeated in January and in February 1991.

The number of spores on an individual butterfiy was determined by a wash and count method rather than scraping and mounting of scales on a slide as described by McLaughlin \& Myers (1970) because the amber coloured spores were difficult to detect on the brown or black scales. Our method involved placing the abdomen or any portion of the butterfly into a $15 \mathrm{ml}$ centrifuge tube containing $10 \mathrm{ml}$ of a $0.05 \%(\mathrm{v} / \mathrm{v})$ wetting agent (Tween 20, J. T. Baker Chemial, Phillipsburg, New Jersey) in deionized water. The body part was washed for spores by agitating the tube vigorously with a vortex mixer for $1 \mathrm{~min}$, let stand for $5 \mathrm{~min}$, and reagitated for another minute. The body part was removed and the wash suspension was centrifuged for $10 \mathrm{~min}$ at $5000 \mathrm{rpm}$ with a bench-top centrifuge (IEC HN-SII centrifuge). The supernatant was discarded, $0.5 \mathrm{ml}$ of the wetting solution was added, and the tube agitated for $10 \mathrm{~s}$ to resuspend the pellet. The number of protozoan sproes was determined with a haemocytometer. The detection of a single spore in the haemocytometer field represented 500 spores.

Once monthly, three female and male butterflies with numerous visually detectable spores on their white scales were selected to determine the spore distribution on their bodies. The head, thorax, wings and abdomen were removed and washed for spores, using the methodology described earlier. The abdomen of each butterfly was divided into proximal, middle and distal sections before being washed for O.elektroscirrha spores.

The length and diameter of ten spores from each of five males and five females from Natural Bridges State Park (NBSP; $36^{\circ} 57^{\prime} 11^{\prime \prime}$ latitude and $122^{\circ} 03^{\prime} 30^{\prime \prime}$ longitude), Santa Cruz County and PRS winter sites were measured. The internal tissues were stained with Giemsa and the alimentary tract, fat bodies, and Malpighian tubules were examined for replicating stages of the protozoan.

Seasonal prevalence of infection. Ten females and ten males were collected bimonthly from December 1990 to February 1991 from NBSP and PRS winter sites. The butterflies, placed individually in envelopes and held in an ice chest, were taken to the laboratory for evaluation of wet body weights (nearest $0.001 \mathrm{~g}$ ), forewing lengths $(\mathrm{mm}$ ) and for the number of neogregarine spores.

Statistical analyses. The data were subjected to the test of normality and homogeneity of variances using the statistical program of Pimentel \& Smith (1990). If ANOVA assumptions were not met, they were analysed using nonparametric analyses of variance such as the Kruskal-Wallis (KW 123), or the Randomization (RANT) tests.

\section{Results}

\section{Neogregarine identification}

The dimensions (length and diameter) of the amber neogregarine spores from male and female butterflies of NBSP and PRS winter sites were similar to those reported by McLaughlin \& Myers (1970) (Table 1). The spore measurements from the butterflies of both winter sites did not differ significantly between the sexes or localities $(\mathrm{F}=0.76 ; P=0.52$, d.f. $=1)$. Observations of dissected and Giemsa-stained tissues of butterflies with external spores showed no micronulear or macronuclear meronts or spores in their internal tissues (i.e. the alimentary canal, Malpighian tubules and fat bodies). Infection seemed to be limited to the hypodermal cells as described by McLaughlin \& Myers (1970). Based on spore morphology, host, and spore location on the host's body, we determined that the protozoan was O.elektroscirrha.

\section{Distribution of spores on the body of the insect}

The spore distribution on the bodies of male and female butterflies was not significantly different and was subsequently pooled and treated as one group. The rank mean of the spores recovered from the head of the butterflies was significantly less than those of the wing, thorax and abdomen (Table 2). Although no significant segregation was detected among the rank means of the thorax, wings and abdomen, Kruskal-Wallis trend analysis indicates that the abdomen had a higher concentration of spores $(\mathrm{H}=29.04, P<0.01$, d.f. $=1$, Table 2$)$. A similar trend was depicted for the spore distribution just on the abdomen. The spore numbers increase in density towards the posterior third of the abdomen $(H=4.97, P<0.05$, d.f. $=1$, Table 2). 
Table 1. Mean $\pm S D$ measurements of spores from scales of female and male monarch butterflies collected from two California winter populations.

\begin{tabular}{lclll}
\hline Locality & $n$ & Sex & Length $(\mu \mathrm{m})$ & Diameter $(\mu \mathrm{m})$ \\
\hline Natural Bridges & 50 & Male & $14.0 \pm 0.1$ & $9.0 \pm 0.1$ \\
& 50 & Female & $14.0 \pm 0.1$ & $8.0 \pm 0.1$ \\
Pismo & 50 & Male & $13.0 \pm 0.1$ & $9.0 \pm 0.1$ \\
& 50 & Female & $14.0 \pm 0.1$ & $9.0 \pm 0.1$ \\
O.elektroscirrha* & 100 & not stated & $14.0 \pm 0.7$ & $8.8 \pm 0.5$ \\
\hline
\end{tabular}

* Measurements from McLaughlin \& Myers (1970).

Table 2. The distribution of Ophryocystis elektroscirrha spores on the monarch butterfly's body. Total sample size is 24 ; mean ranks and variance presented for body regions and mean and $\mathrm{SE}$ for abdominal spore counts.

\begin{tabular}{llrr}
\hline Body region & Mean ranks* & \multicolumn{1}{c}{ Variance } & \multicolumn{1}{l}{ Mean SE } \\
\hline Head & $22.6^{\mathrm{a}}$ & \pm 103.9 & $(2,940 \pm 1,040)^{\dagger}$ \\
Thorax & $50.8^{\mathrm{b}}$ & $\pm 10,328.5$ & $(33,375 \pm 10,370)$ \\
Wings & $53.3^{\mathrm{b}}$ & $\pm 10,879.8$ & $(36,375 \pm 10,645)$ \\
Abdomen & $67.4^{\mathrm{b}}$ & $\pm 123,354.5$ & $(167,980 \pm 35,845)$ \\
Abdomen & & & \\
$\quad$ Proximal third & & $33,730 \pm 9,335$ \\
$\quad$ Middle third & & $50,000 \pm 12,375$ \\
Distal third & & $84,250 \pm 18,960$ \\
\hline
\end{tabular}

* Randomization test; value with different letter in a column is significant at $P<0.05$.

${ }^{\dagger}$ Mean and SE of original data.

\section{Survival of spore-laden butterflies under laboratory conditions}

The frequency of individuals with abdominal spores of $0<500$ spores, $500-50,000$ and $>50,000$ collected during December, January and February showed that it did not vary significantly $(F=0.00, P=1.00$, d.f. 2 ; Table 3$)$ during those months.

Butterflies held at $10.1^{\circ} \mathrm{C} \pm 0.1 \mathrm{SE}$ and $78.3 \%$ r.h. \pm 0.6 SE had significantly lower rates of body moisture loss (RBML) (calculated by subtracting the freeze dried weight from the wet weight and dividing the result by the number of days the butterfly survived) than butterflies held at $19.1^{\circ} \mathrm{C} \pm 0.4 \mathrm{SE}$ and $44.9 \%$ r.h. $\pm 1.5 \mathrm{SE}(0.02 \pm 0.00 \mathrm{SE}$ v. $0.04 \pm 0.0 \mathrm{SEg} /$ day; $\mathrm{F}=42.23, \quad P<0.01$, d.f. $=1$ ). At $10.1^{\circ} \mathrm{C}$ and $78.3 \%$ r.h., butterflies with detectable spores survived as long as those without detectable spores $(19.78 \pm 0.36 \mathrm{SE} v .19 .19 \pm 0.31 \mathrm{SE}$ days; $\mathrm{F}=1.37$, $P=0.24$, d.f. $=1)$ and did not differ significantly in the RBML $(0.02 \pm 00 \mathrm{SE} v .0 .02 \pm 0.02 \mathrm{SE}$ g/day; $\mathrm{F}=0.03$, $P=0.87$, d.f. $=1$ ). The butterflies survived significantly longer on honey water or water diet than without liquid $(19.79 \pm 0.04 \mathrm{SE}$ and $20.17 \pm 0.38 \mathrm{SE} v .18 .25 \pm 0.43 \mathrm{SE}$ days; $\mathrm{F}=6.16, P<0.01$, d.f. $=2$ ).
Table 3. Three frequency categories of monarch butterflics with Ophryocystis elektroscirrha spores collected in December 1990 and January and February 1991 from Pismo Ranger Station, California.

\begin{tabular}{llll}
\hline & \multicolumn{2}{l}{ Spore categories } \\
\cline { 2 - 4 } Month & $0<500$ & $500-50,000$ & $>50,000$ \\
\hline December & 34 & 45 & 11 \\
January & 34 & 39 & 17 \\
February & 30 & 42 & 18 \\
\hline
\end{tabular}

The infected butterflies held at $19.1^{\circ} \mathrm{C}$ and $44.9 \%$ r.h. showed significantly higher rates of body moisture loss $(0.04 \pm 00 \mathrm{SE} \quad v .0 .03 \pm 0.00 \mathrm{~g} / \mathrm{day} ; \mathrm{F}=8.78, \quad P<0.01$. d.f. $=1)$ than those without detectable abdominal spores $(0<500$ spores). The rates of body moisture loss was not different for butterflies with 500-50,000 spores and those with $>50,000$ spores (Table 4 ). Individuals with greater numbers of abdominal spores $(>50,000)$ had a significantly shorter survival period than those without detectable 
Table 4. The relationship of number spores on the abdomen to the rate of body moisture loss and to the longevity of the monarch butterflies held at $19.1^{\circ} \mathrm{C} \pm 0.4 \mathrm{SE}$ and $44.9 \%$ r.h. $\pm 1.5 \mathrm{SE}$ for 21 days.

\begin{tabular}{|c|c|c|c|c|c|}
\hline \multirow{2}{*}{$\begin{array}{l}\text { No. of abdominal } \\
\text { spores }\end{array}$} & \multirow[b]{2}{*}{$n$} & \multicolumn{2}{|c|}{$\begin{array}{l}\text { Rate of body } \\
\text { moisture loss } \\
\text { (g/day) }\end{array}$} & \multicolumn{2}{|c|}{$\begin{array}{l}\text { Longevity } \\
\text { (days) }\end{array}$} \\
\hline & & Mean* & SE & Mean* & $\mathrm{SE}$ \\
\hline $0<500$ & 94 & $0.03^{\mathrm{a}}$ & \pm 0.00 & $16.4^{\mathrm{a}}$ & \pm 0.7 \\
\hline $500-50,000$ & 123 & $0.04^{\mathrm{b}}$ & \pm 0.00 & $14.0^{\mathrm{ab}}$ & \pm 0.7 \\
\hline$>50,000$ & 53 & $0.05^{b}$ & \pm 0.01 & $12.4^{\mathrm{b}}$ & \pm 1.0 \\
\hline
\end{tabular}

* Value followed by a different letter is significant at $P<0.01$

$(<500)$ spores $(12.38 \pm 1.02 \mathrm{SE}$ days $v .16 .42 \pm 0.68 \mathrm{SE}$ days; $\mathrm{F}=5.92, P<0.01$, d.f. $=2$; Table 4 ).

At $19.1^{\circ} \mathrm{C}$ and $44.9 \%$ r.h., insects fed honey-water mixture did not differ significantly from those fed deionized water in their rate of body moisture loss. Both groups, however, had a significantly lower rate of moisture loss than those provided no liquid $(0.02 \pm 00 \mathrm{SE}$ and $0.03 \pm 0.00$ v. $0.07 \pm 0.00 ; \mathrm{F}=48.50, P<0.01$, d.f. 2 ). The female butterflies had a significantly greater rate of body moisture loss than the males $(0.05 \pm 0.01 \mathrm{SE}$ g/day $v .0 .03 \pm 0.00$ $\mathrm{SEg}$ /day; $\mathrm{F}=10.7, P<0.01$, d.f. 1$)$, but this difference in moisture loss was not related to their longevity $(14.08 \pm$ $0.64 \mathrm{SE}$ days $v$. $14.99 \pm 0.62 \mathrm{SE}$ days; $F=1.05, P=0.31$, d.f. 1).

\section{Seasonal prevalence of infection}

Neogregarine spores were detected on a high percentage of overwintering butterflies collected from both winter sites. Butterflies collected from NBSP had detectable infection rates of $66.7 \% \pm 6.2 \mathrm{SE}$ for females and $68.3 \%$ $\pm 7.0 \mathrm{SE}$ for males. At PRS, $55.0 \% \pm 8.8 \mathrm{SE}$ of the female butterflies and $53.3 \% \pm 3.3 \mathrm{SE}$ of the males were infected. Although butterflies from NBSP had a higher proportion of infected individuals than PRS, the infection rates at both winter sites were not significantly different $(F=0.93$, $P=0.55$, d.f. $=3$ ). Similarly, the average number of spores detected on each male and female $(>500)$ within and between winter sites was not significantly different $(F=0.61$, $P=0.61$, d.f. $=3 ; 50,450 \pm 15,150 \mathrm{SE}$ for females and $51,150 \pm 11,550$ SE for males at NBSP; 46,100 $\pm 13,500 \mathrm{SE}$ for females and 72,850 $\pm 17,500 \mathrm{SE}$ for males at PRS). The proportion of the sexes and the general population carrying spores at both winter populations remained relatively constant during the 3-month survey.

Butterflies with neogregarine spores had similar forewing lengths as those without detectable body spores $(50.0 \mathrm{~mm} \pm 0.14 \mathrm{SE} v .50 .3 \mathrm{~mm} \pm 0.17 \mathrm{SE} ; \mathrm{F}=1.82, P=$ 0.18 , d.f. $=1$ ).

\section{Discussion}

Although a high percentage of monarch butterflies were infected with O.elektroscirrha under natural conditions, the protozoan is not a significant mortality factor. Under laboratory conditions of $10.1^{\circ} \mathrm{C}$ and $78.3 \%$ r.h., butterflies with detectable spores survived just as long as those without detectable spores. These conditions were similar to the average temperatures and relative humidities associated with trees on which the butterflies aggregated during the same three survey months $\left(10.3^{\circ} \mathrm{C} ; 77 \%\right.$ r.h. and $10.1^{\circ} \mathrm{C} ; 80 \%$ r.h. for NBSP and PNB, respectively). The rates of moisture loss between butterflies held at $10^{\circ} \mathrm{C}$ and $78 \%$ r.h. were significantly less than those held at $19.1^{\circ} \mathrm{C}$ and $44.9 \%$ r.h. Perhaps the reason for the high survival rate of protozoan infected individuals during the winter months may be attributed to the cool, moist conditions that exist in the winter grove. Overwintering butterflies are often found in groves associated with the coastal fog belt and aggregate on selected trees that offer shelter from gusty winds and direct sun (Frey et al., 1992; Leong, 1990; Leong et al., 1991).

At conditions of $19.1^{\circ} \mathrm{C}, 45 \%$ r.h., butterflies with detectable body spores showed a significantly greater rate of moisture loss and a shorter longevity than those with nondetectable body spores. The results suggest that the integument of butterflies with detectable spores may have been altered due to the neogregarine infection of the hypodermal cells. Since the hypodermal cells are responsible for the integument of the insect, conceivably the cuticle of infected butterflies is modified to allow greater evaporation rate resulting in a shorter survival rate. The degree of integument change, however, is not associated with the number of spores recovered from the affected butterflies, because the rates of moisture loss are the same for individuals with $500-50,000$ or with $>50,000$ spores. Possibly, any cuticular disruption that allows body moisture losses greater than $0.05 \mathrm{~g} /$ day will be detrimental to the butterflies. Such individuals may die shortly after emergence or die while migrating to their winter sites. Although there are no differences in the rates of body moisture loss between individuals with 500-50,000 and $>50,000$ body spores, the latter seems weaker since their longevity is shorter than butterflies of the former category. McLaughlin \& Myers (1970) postulated that affected individuals are weaker and our results seems to support their hypothesis.

The complete life cycle of O.elektroscirrha has not been established, but the concentration of spores on the abdominal scales, particularly on the posterior third, suggests two probable methods of transmission: horizontal and vertical (Andreadis, 1987). The transfer of spores from infected male to healthy female during mating (horizontal transmission) seems likely. This type of venereal transfer occurs with other pathogens, e.g. viruses (Zelazny, 1976; Martignoni \& Milstead, 1962), bacteria (Bucher, 1963), protozoa (Brooks, 1988) and nematodes (Simmons \& Rogers, 1990). Infected and/or contaminated females undoubtedly transmit the pathogen vertically as a result 
of transovum transmission. Infected adults may also contaminate the food source and the healthy larvae may consume the spores. Significant larval to larval transmission does not occur because no spores are produced until the pupal stage. Larvae upon hatching, however, may consume the spores on the chorion. Other spores may be defecated, contaminating the leaves, and may serve as a potential source of infection for healthy larvae.

\section{References}

Andreadis, T.G. (1987) Transmission. Epizootiology of Insect Diseases (ed. by J. R. Fuxa and Y. Tanada), pp. 159-176. John Wiley \& Sons, New York.

Brooks, W.M. (1988) Entomogenous protozoa. CRC Handbook of Natural Pesticides, Vol, 5, Microbial Insecticides, Part A, Entomogenous Protozoa and Fungi (ed. by C. M. Ignoffo), pp. 1-149. CRC Press, Boca Raton, Florida.

Bucher, G.E. (1963) Survival of populations of Streptococcus faecalis Andrewes and Horden in the gut of Galleria mellonella (Linnaeus) during metamorphosis, and transmission of the bacteria to the filial generation of the host. Journal of Insect Pathology, 5, 336-343.

Frey, D., Leong, K.L.H., Fredericks, D. \& Raskowitz, S. (1992) Clustering patterns of monarch butterflies (Danaus plexippus (L.); Danaidae: Lepidoptera) at two California central coast overwintering sites. Annals of the Entomological Society of America, 85, 148-153.

Jouvenaz, D.P. \& Anthony, D.W. (1979) Mattesia geminata sp.n. (Neogregarinida: Ophrocystidae) a parasite of the tropical fire ant Solenopsis geminata (Fabricius). Journal of Protozoology. 26, 354-356.

Leong, K.H.L. (1990) Microenvironmental factors associated with the winter habitat of the monarch butterfly (Lepidoptera: Danaidae) in central California. Annals of the Entomological Society of America, 83, 907-910.

Leong, K.H.L., Frey, D., Brenner, G., Baker, S. \& Fox, D. (1991) Use of multivariate analyses to characterize the monarch butterfly (Lepidoptera: Danaidae) winter habitat. Annals of the Entomological Society of America, 84, 263-267.

Martignoni, M.E. \& Milstead, J.E. (1962) Trans-ovum transmission of a nuclear polyhedrosis virus of Colias eurytheme Boisduval through contamination of female genitalia. Journal of Insect Patholology, 4, 113-121.

McLaughlin, R.E. \& Myers, J. (1970) Ophryocystis elektroscirrha sp.n., a neogregarine pathogen of the monarch butterfly Daraus plexippus (L.) and the Florida queen butterfly D.gilippus berenice Cramer. Journal of Protozoology, 17, 301)-305.

Pimentel, R.A. \& Smith, J.B. (1990) Biostat I: a univariate statistical tool box, 2nd edn. Sigma Soft, Placentia, Calif.

Simmons, A.M. \& Rogers, C.E. (1990) Temperature and humidity effects on Noctuidonema (Nematoda: Aphelenchoididae), an ectoparasite of adult Spodoptera frugiperda (Lepidoptera: Noctuidae), and transfer success during host mating. Annals of the Entomological Society of America, 83, 1084-1087.

Weiser, J. (1963) Sporozoan infections. Insect Pathology, Vol. 2 (ed. by E. A. Steinhaus), pp. 291-334. Academic Press, New York.

Zelazny, B. (1976) Transmission of a baculovirus in populations of Oryctes rhinoceros. Journal of Invertebrate Pathology, 27, 221-227. 